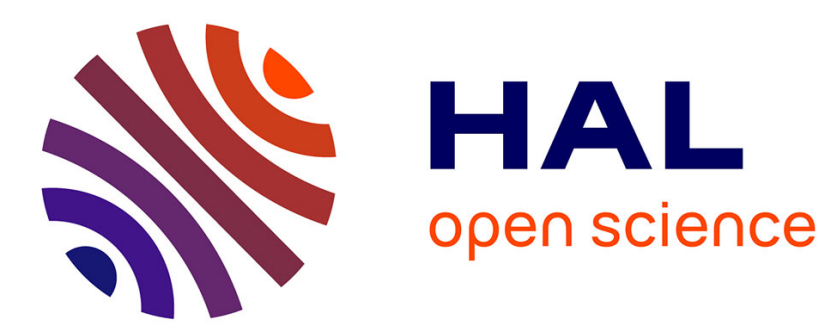

\title{
Policy beyond politics? Public opinion, party politics and the French pro-nuclear energy policy
}

\author{
Sylvain Brouard, Isabelle Guinaudeau
}

\section{To cite this version:}

Sylvain Brouard, Isabelle Guinaudeau. Policy beyond politics? Public opinion, party politics and the French pro-nuclear energy policy. 2013. halshs-00911445

\section{HAL Id: halshs-00911445 \\ https://shs.hal.science/halshs-00911445}

Preprint submitted on 29 Nov 2013

HAL is a multi-disciplinary open access archive for the deposit and dissemination of scientific research documents, whether they are published or not. The documents may come from teaching and research institutions in France or abroad, or from public or private research centers.
L'archive ouverte pluridisciplinaire HAL, est destinée au dépôt et à la diffusion de documents scientifiques de niveau recherche, publiés ou non, émanant des établissements d'enseignement et de recherche français ou étrangers, des laboratoires publics ou privés. 


\section{Sciences Po Grenoble working paper n.6}

Policy beyond politics? Public opinion, party politics and the French pro-nuclear energy policy

Sylvain Brouard, Centre Émile Durkheim - Sciences Po Bordeaux Isabelle Guinaudeau, Univ. Grenoble-Alpes, Sciences Po Grenoble, PACTE

\section{November 2013}

Partners //

$P$ a c t e

UNITÉ MIXTE DE RECHERCHE CNRS 


\title{
Policy beyond politics? Public opinion, party politics and the French pro-nuclear energy policy. ${ }^{1}$
}

\author{
Sylvain Brouard, Centre Émile Durkheim - Sciences Po Bordeaux \\ s.brouard@sciencespobordeaux.fr
}

Isabelle Guinaudeau, Pacte - Sciences Po Grenoble

Isabelle.guinaudeau@sciencespo-grenoble.fr

\begin{abstract}
:
At first sight, French nuclear energy policy offers a textbook example of how technical, constitutional and economic restrictions, powerful interest groups, and path dependence, constrain democratic responsiveness. This paper uses what might seem to be an unlikely case in order to question explanations of policy choices in terms of technocracy, path dependence, and interest groups, against the background of an underestimated factor: party and coalition strategies. The original data collected on public attitudes towards nuclear energy, and the attention dedicated to this issue in the media, as well as in the parliamentary and electoral arenas, show that the effect of public opinion is conditioned by party incentives to politicize the issue at stake. In other words, parties and coalition-making constraints act as a mediating variable between citizens' preferences and policy choices. These findings point to the need to integrate this conditional variable into analyses of responsiveness and models of policymaking.
\end{abstract}

\footnotetext{
${ }^{1}$ We would like to thank Wolfgang Müller, Paul Thurner and the participants to the PONEE project for their helpful comments and for initially stimulating our interest in the politics and policy of nuclear energy. We are also grateful to the participants of the Comparative Agendas Project meeting at Den Haguen (2009), as well as the members of the French Agendas Project for their constructive discussion. We owe a lot to Pepper Culpepper for his active support and his numerous relevant suggestions, as well as to the anonymous reviewers who provided us with meaningful advice. The data was collected thanks to the generous support of the French Research Agency (ANR Agendas and ANR Legipar). Isabelle Guinaudeau would also like to thank the Max Weber Programme for work completed on this article under the Max Weber Fellowship.
} 


\section{Introduction}

Responsiveness towards public opinion is commonly considered to be at the core of any liberal democracy. Beyond normative principles (e.g. Schumpeter 1942; Pitkin 1967; Dahl 1971), representatives concerned with re-election may perceive incentives to respond in their policies to the preferences of the median voter (Downs 1957; see also the idea of "rational anticipation" developed by Stimson et al. 1995). The "responsiveness" literature has, indeed, observed a strong link between public opinion and policy decisions (e.g. see Jacobs and Shapiro 1994 for an overview).

However, interest in this factor comes mainly from specialists in public opinion, and has not yet been integrated systematically into public policy research. There is a growing academic awareness that politics tend to be neglected, or at least under-estimated, in the public policy literature (e.g. Bale 2008; Zohinhöfer 2009; Mortensen et al. 2011). As observed by some authors, the focus is mostly set on other factors, in particular path dependence, institutional friction, cognitive constraints, and the weight of interest groups, to the detriment of politics. Responsiveness is sometimes even seen to be increasingly constrained by factors that include the internationalization of the economy, the Europeanization of public policies, limited budgetary and energy resources, and aging populations. These constraints restrict the margins for manoeuver policymakers have available with which to respond to citizens' demands and to fulfill electoral promises.

Should we thus conclude that policies are increasingly made beyond public opinion, and that popular demands are a negligible factor for those who study policymaking? What to do then with the results of the "responsiveness" literature? To rigorously address these questions, identifying the determinants of the variations in responsiveness is the most promising approach. Two factors have been investigated: issue salience and institutions. This article emphasizes a third factor - party politics - that has been underestimated so far in the academic debate on policymakers' responsiveness to public opinion, even if parties have been described as the key players of modern democracy. ${ }^{1}$

Based on a study of French choices in nuclear energy policy, this article enquires into the process by which public opinion is translated (or not) into public policy, and it underlines the crucial role played by issue politicization in party competition. After a brief review of the public policy literature through the lens of democratic responsiveness (section 1), we show that the unique stability and weight of the French nuclear power program (section 2) cannot be explained using a simple "public opinion" explanation: we observe considerable skepticism towards nuclear energy in French public opinion, and mass protest against it (section 3). Yet, even regarding this textbook example of the configuration of factors likely to constrain democratic responsiveness (with a highly technical and complex nature, a heavy and growing path dependence, and the combination of considerable financial, economic, geostrategic, technical and natural constraints), the disconnection between public opinion and public policy does not imply that responsiveness is irrelevant to nuclear energy policy. Our analysis of original longitudinal data on atomic policy in several political arenas, public opinion, the media and party discourses, leads us to question explanations in terms of technocracy and constraints (section 4), against the background of the underestimated factor of party and coalition strategies (section 5). Public opinion appears to be relevant to policymaking, but it does not exert an automatic influence: for responsiveness to occur, the issue at stake has to be politicized by at least one political party. Models of responsiveness should thus consider the conditional influence of parties' strategic incentives to politicize 
policies, in particular with respect to the inter-party dynamics of contention across diverse issues and with the related coalition-making constraints.

\section{1) Bringing parties into accounts of democratic responsiveness}

Responsiveness to voters is commonly considered to be a central aspect of democracy. At least, in all liberal conceptions of democracy, representatives are expected to be responsive to the priorities and the expectations of the citizens they represent. In line with this normative principle, the "responsiveness" literature has a long tradition of studies that indicate that public opinion, as expressed by polls, mobilizations, and mass-mediated discourses, contributes to the shaping of policies (e.g. Page and Shapiro 1983; Hartley and Russett 1992; Hill and Hinton-Andersson 1995; Stimson et al. 1995; Burstein 1998; Stimson 1999; Manza and Cook 2002; Soroka 2002; Hakhverdian 2010), using sophisticated conceptualizations, such as the "thermostatic model" (Wlezien 1995; Wlezien 2004; Soroka and Wlezien 2010; Hakhverdian 2012).

However, the link between public preferences and public policy has not yet been established in sufficient detail. First, studies of responsiveness tend to focus geographically on the United States, Canada, and sometimes Britain, and to rely on row indicators, such as the general "public mood", the left-right positioning of voters, the level of spending, or the broad issue attention of voters and legislators, which do not allow to capture more fine-grained policy expectations and decisions. Second, a series of political and academic discourses highlights the constraints that restrict the margins for manoeuver policymakers have available with which to fulfill electoral promises and to respond to citizens' demands (e.g. Rose 1984; Pierson 2000). From this point of view, given the internationalization of the economy, the Europeanization of public policies, the limited budgetary and energy resources, aging populations and, recently, constraints linked to the functioning of financial markets, the available political space is swiftly, and dramatically, shrinking (see Arnold and Franklin 2012 or Persico et al. 2012 for an overview). Some politicians invoke such trends to advocate a managerial or technical conception of policymaking, characterized by the search for efficient solutions, rather than by decisions reflecting popular preferences.

Perhaps because of this context, the interest in responsiveness stems mainly from specialists in public opinion, and it has not yet been integrated systematically into public policy research. Public opinion, and politics more generally, tends to be left out of policy analyses to the benefit of other factors, such as institutional friction, cognitive constraints, path dependence, and the weight of parallel channels, notably the representation of corporatist interests. The growing irrelevance of "responsiveness" in contemporary democracies has become a conventional wisdom (Jacobs and Shapiro 2000; Mair 2006). However, when empirically assessed, the claim of the growing irrelevance of responsiveness relies on studies either designed at a very high level of aggregation, or operationalized in a crude way, with policy preferences and choices defined only in terms of status quo vs. change (e.g. Monroe 1998; Gilens 2005). In addition, and as already suggested, much of the public policy literature ignores public opinion, or seems to postulate its irrelevance rather than to demonstrate it. There is no empirical reason to leave out public opinion a priori from public policy analyses and the existing accounts of responsiveness stemming from public opinion studies indicates, at least in some cases, that this factor does matter.

Faced with the mixed nature of the available results, a promising research avenue consists in exploring the conditions under which public opinion may affect policies. A small number of studies has demonstrated the potential of this research agenda by establishing the significant 
conditioning influence of political institutions (Wlezien and Soroka 2012), government popularity (Erikson et al. 2002; Hobolt and Klemmensen 2008) and issue salience (Monroe 1998; Gilbert and Henry 2009; Culpepper 2011). This article contributes to this line of research, with a focus on an underestimated factor: party politics, coalition-making constraints and the related incentives for parties to politicize choices of public policy. Our main hypothesis is that, even regarding salient topics, public opinion does not exert any automatic influence on policies: for popular demands to be translated into decisions regarding a particular issue, this issue has to be politicized by at least one party. Conversely, a lack of responsiveness may not be due to constraints, path dependence, technocracy or interest groups, but to a lack of incentives for parties to politicize specific issues.

As a salient problem, if yet a highly technical one, marked by considerable constraints and path dependence (Baumgartner 1990; Baumgartner and Jones 1993), French nuclear energy policy offers an intriguing field of study with which to test this hypothesis. Even in this unlikely case in which to find partisan influence and democratic responsiveness, the following analysis of original longitudinal data on atomic policy in several political arenas, public opinion, the media and party discourses, leads us to question explanations in terms of technocracy and constraints. Instead it confirms the key role of party and coalition strategies in the disconnection between public preferences and French nuclear energy policy.

\section{2) French nuclear energy: an unlikely case of democratic responsiveness?}

\section{Policy decisions characterized by their stability}

Contrary to most Western countries where nuclear policy programs were discussed or launched, France never experienced any nuclear policy reversal. In this respect, it appears as a real outsider, sharply contrasting with most other countries. In 1978, Austria renounced any use of nuclear energy, before the first plant was even switched on. In the same year, a Swedish referendum decided on a progressive phasing-out of the use of nuclear energy. Later reversals occurred after the accident at Three Mile Island, which prompted the United States and the United Kingdom, pioneers in nuclear development, to stop their plant construction program, and at Chernobyl, after which referendums decided the end of Italian nuclear electricity production (1987), and a moratorium on the construction of new nuclear plants in Switzerland (1990). The subsequent rise of Green parties, and their participation in governments, led to further policy reversals in the 1990s, notably in Belgium (1999) and in Germany (2000), where votes led to a progressive phasing-out. The 2000s saw a series of new reversals in favor of the nuclear industry, leading some observers to announce a "nuclear renaissance" (see Findlay 2011:1 for book examples). The Belgian, American, Italian, British and German governments took measures to revive or extend their nuclear industry, while the Swedish moratorium on the construction of new plants was lifted in 2009. Most recently, the Fukushima accident resulted in a new series of reversals, in Germany, Japan and Italy, where decisions were taken to phase out the use of nuclear energy.

Against this background, French nuclear policy distinguishes itself by its stability. French nuclear policy can be traced back to 1945, when the Commission for Atomic Energy (CEA) was created as a specialized nuclear research center. This decision reflected three motives: a scientific ambition to deeply involve the French research community in nuclear research; an interest linked to the potential of a civilian use of nuclear energy for electricity production in the context of post-war reconstruction; and the objective to develop nuclear weapons in order 
to avoid a new military defeat and to gain independence from the United States and the Soviet Union (Hecht 1998).

In 1951, the minister Félix Gaillard proposed the first 5-year plan for the development of nuclear energy, which was adopted a year later by the National Assembly, despite the Communist MPs' reluctance for any military use of atomic power, and the concern of rightist parties to prevent the participation of communist sympathizers in the program. This plan gave birth to the first nuclear plant in 1956, and to the development of a second one, built in 1959. Framed in terms of independence and industrialization, the electricity production program did not rely on existing American technology, but on new French technology (using graphite), developed by the CEA. EDF, the electricity company nationalized in 1945, succeeded in setting-up a collaboration with the CEA on the first nuclear plant, and was able commercially to deploy electricity produced by nuclear energy from 1966.

The association and balance between the CEA and EDF structured the nuclear policy field in the 1960s, crucial years for French nuclear policy (Hecht 1998). While the CEA, along with the army, was focused on French nuclear independence and the production of plutonium for the nuclear weapons program, the EDF primarily sought to intensify electricity production, and thus favored the more efficient and robust American technology, based on pressurized water reactors, rather than graphite-moderated reactors. In 1969, the government decided to split the military and the civilian wings, and allowed the EDF to use its preferred technology. This decision directly resulted in the building of a new series of nuclear plants. The commitment to this industrial perspective occurred before the oil crisis of 1973-1974, but the crisis reinforced it. The "Messmer plan", adopted in 1974, scheduled the construction of 13 new plants before 1980, 50 before the middle of the 1980s, and 200 before 2000. This overweening program was only partially realized, given the over-estimation of the growth in electricity consumption in France (Bataille and Galley 1999; see also Guillaumat-Tailliet 1987). In 1973, the forecast of electricity needs for 2000 was $1000 \mathrm{TWh}$; in 1980, $650 \mathrm{TWh}$; in 1983, 500 TW. Finally, in 2000, the actual demand for electricity was around $450 \mathrm{TWh}$.

This nuclear policy was not contested in Parliament until 1997, and anti-nuclear stances were kept outside political institutions (Nelkin and Pollak 1981; Kitschelt 1986; Rucht 1994). However, the 1970s were marked by an upsurge in opposition to nuclear plants. Protests ran from local action to massive demonstrations, with violent confrontations with the police, reaching a peak of mobilization in Creys-Malville, against the Superphénix fast-breeder reactor, in 1976 and 1977. The anti-nuclear protests persisted in the early 1980s, with only limited policy results. The building of nuclear plants was briefly suspended after Mitterrand's election, in order to allow for an assessment and a policy debate in parliament. The only cancellation, in 1981, in the construction of a new nuclear plant was that planned in Plogoff. The decision to slow down the construction of new plants was only weakly related to popular protest, but was due rather to the overproduction of electricity by the EDF.

The 1998 decision to stop the Superphénix plant, a subject we will return to in greater detail below, was part of the agreement of the government coalition between the Socialist, Communist and Green parties. This was highly symbolic for opponents of nuclear energy, given the numerous demonstrations this experimental plant had provoked over two decades. Nevertheless, the level of nuclear energy production remained unaffected, and even kept on growing. In the $2000 \mathrm{~s}$, despite a still positive annual balance in the electricity trade ${ }^{2}$, the surplus has been shrinking, and imports are regularly needed in winter, due to the decreasing availability in French plants, as a result of aging and maintenance issues (Delion and Durupty 2010: 173). After a 15 years pause (1990-2005), these trends have motivated the decision to 
extend the service life of existing plants and to build several EPR reactors in France. This new development phase was revised downwards in 2009, in view of stagnating energy needs, but was not seriously called into question after the Fukushima accident.

\section{A policy of major importance}

This unique continuity of a pro-nuclear policy has generated the second largest set of nuclear plants in the world (58 reactors), behind the United States (104). French investitions in nuclear research and development, as well as in nuclear facilities, between the beginning of the program and 2010, are estimated to over 83 billion Euros. ${ }^{3}$ As a result, France was able to reduce (until the mid-1980s), and then to stabilize, its oil imports, as well as to triple its energy production since the 1970s, despite the decline of domestic natural resources (coal, gas, oil). So, notwithstanding scarce domestic natural resources, the level of dependence on foreign energy has regularly decreased, falling below 50\%, and France is able to export electricity (Guillaumat-Tailliet 1987; Hadjilambrinos 2000). Nuclear energy represents 80\% of French energy production, and almost the same proportion of French electricity consumption, which makes France worldwide the country relying most on this energy.

The significance of the French nuclear program should also be evaluated with respect to the central importance of the state-owned nuclear sector to French industrial policy. The main justification for this persistent state control is the French concept of mission de service public, which implies guaranteeing an equal and universal access to electricity - objectives defined in the 2000 law on electricity. Yet, the giant (partly) state-owned companies are also a pillar of French industrial and commercial policy. The state has favored concentration in the energy sector and encouraged competition between major groups. ${ }^{4}$ This 'policy of champions', and the technological advantage gained through the almost continuous expansion of the nuclear industry, fostered the emergence of high-performing and competitive groups that are successfully following a strategy of internationalization (Chick 2007; Delion and Durupty 2010). Most notably, worldwide, Areva and EDF are respectively the leading groups in the nuclear energy sector and the first electricity producer and provider.

How can we explain this French exception? The resolute involvement in the nuclear option may not plausibly be fully explained by the background of a lack of natural resources. Other countries suffering from their incapacity to meet a strong industrial and domestic demand with domestic gas, oil, mines or renewable energy sources, Germany in particular, made distinct policy choices. In most cases, phasing-out decisions resulted from the successful mobilization of anti-nuclear movements and parties, along with a hostile climate of opinion (Hatch 1986; Jasper 1990; Jopke 1993; Baisnée 2001). Was public opinion more supportive in France than in other countries, was anti-nuclear contestation less mobilized? Or were public and ecologist preferences not channeled into the process of policymaking? If so, what made possible such an absence of democratic policy feedback regarding such a crucial political, economic, and industrial issue?

\section{3) Nuclear power and French citizens: beyond the myth of a love story.}

\section{A pro-nuclear public mood?}

Public contestation over nuclear energy is considered to be a crucial factor for policy reversals, as well as a potential constraint for the future development of nuclear infrastructures. As Findlay puts it, "many of the factors are matters of contention and 
controversy, most obviously the question of the economic feasibility of new nuclear build and the challenges of nuclear waste disposition. The fact that these issues generate controversy creates uncertainty for governments, industry and private financiers considering investing in nuclear energy. This uncertainty itself acts as a brake on a nuclear energy revival." (Findlay 2011; see also Ramana 2011). Public opinion is sometimes considered to be overwhelmingly pro-nuclear in France. The continuity of French nuclear policy could indeed have been favored by broad popular support.

Testing this hypothesis implies estimating the level of support for nuclear energy and its longterm evolution, a tricky enterprise, given constraints linked to data on attitudes towards nuclear energy (Jasper 1988). After having gathered as much data as possible, enabling us to assess this level of public support, we have to acknowledge the highly heterogeneous nature of our dataset, in terms of frequency, timing and response categories. Some items were asked about only once or twice, response categories and the wording of questions changed over time, and different questions lead to different answers, with strong framing and priming effects. $^{5}$

In order to deal with data heterogeneity, we resorted to the "public mood" indicator, developed by James Stimson in his study of liberalism vs. conservatism in the United States (Stimson 1999). Based on the 'Dyadic Ratio Algorithm', the measure of public mood has been used increasingly to create a single public opinion indicator from heterogeneous datasets (Baumgartner, De Boef et al. 2008 ; Stimson et al. 2010). The "public mood" is an aggregate measure, based on survey marginals. By capturing the shared variation, over time, of different series loading on the same dimension, this measure offers an opportunity to neutralize bias induced by the wording of questions. Following Stimson's guidelines, we included in our indicator of public mood towards nuclear energy all questions asked at least three times over time, which allow a clear and symmetric distinction between positive and negative attitudes towards nuclear energy (See Appendix 1). ${ }^{6}$ We used the ratio of positive feelings, out of the sum of positive and negative feelings for each question, to compute a 'nuclear support index' that estimates the relative level of nuclear support in France. ${ }^{7}$ The French "public mood" towards nuclear energy was computed using the software WCalc, and is based on 302 estimates of the 'nuclear support index' from 24 different question wordings, collected from 13 sources (surveys and barometers). The data obtained, depicted in Figure 1, covers 39 years from 1975 to 2012.

Figure 1 about here

This new indicator delivers several interesting conclusions. The first striking observation is, regarding most of the period considered, the absence of majority support for nuclear energy among French citizens. Despite the bias of our support index towards more support (since this indicator measures the proportion of supportive respondents among those who positioned themselves, this proportion would be substantially lower when calculated in relation to the whole sample), our index exceeds 50\% only over the 1975-1987 period, with values situated between $47,9 \%$ and $60,9 \%$ and an average of 55,1\%. This timing is surprising, as it is set against the background of the strongest anti-nuclear mobilizations in French history.

The Three Mile Island accident in 1979 does not seem to have had any short-term impact at this aggregate level (as the early 1980s mark a peak in support for nuclear energy), but this support declined over the 1980s, especially after the Chernobyl accident in 1986. This trauma caused a rapid collapse, with a drop by 18,8 points in the public mood within 5 years. Interestingly, perhaps due to the fading memory of Chernobyl, or due to the increasing 
visibility of alternative framings, this trend was reversed in the 1990s, marked by a progressive and incremental increase until 2000 - paradoxically, by the mid-term of the Jospin government, which involved the Green Party for the first time.

However, even when the mood indicator reaches a peak in 2000 , it remains under $48,0 \%$, and the 2000s see a new low in the public mood towards nuclear energy, with values between $44,0 \%$ and 48,0\%. Eventually, the increase in support observed in 2012 may be surprising at first sight, in the aftermath of the Fukushima accident and in the context of the diminishing support of public opinion for nuclear power plants in most countries (Ramana 2011; Bonneval and Lacroix-Lasnoë 2011), the phasing-out decided by four of France's direct neighbors and the reflections on the safety of the French plants. As shown elsewhere, this development can be understood with respect to the reframing of nuclear energy, which goes hand in hand with its stronger presence in the media (Brouard et al. 2013). The members of the executive and the leaders of their party have successfully emphasized the jobs, the industrial advantages linked to the nuclear sector, but also its merits in terms of $\mathrm{CO} 2$ emissions. Faced with this right-wing offensive, the ecologists did not manage to impose their framing in terms of risks. It is still too soon to assess the long-term effects of the Fukushima related debates but we should notice that in 2012, our indicator of support for nuclear energy indicates a sharp rise.

The public mood indicator computed allows, for the first time, to estimate the climate of opinion towards nuclear energy among French citizens, and its evolution over almost four decades, with a correction of bias linked to the wording of questions. This series indicates that French public support for the production of nuclear energy is far from broad, and only exceptionally reaches the majority of respondents. This ambivalent, sometimes skeptical, climate of opinion historically found its expression in a relatively strong social mobilization against nuclear energy (Nelkin and Pollak 1981; Kiersch and von Oppeln 1983; Kitschelt 1986; Jasper 1990; Rucht 1994; Kriesi et al. 1995; Baisnée 2001). Stemming mainly from the ecologist movement, groups such as Greenpeace, and from local collectives, like "Stop Golfech", "Tchernoblaye" or the initiatives in the network "Sortir du nucléaire", this contestation took various forms, from petitioning and mobilizing to mass demonstrations or spectacular actions. French anti-nuclear mobilizations were vigorous in the 1970s, after the Three Mile Island and Chernobyl accidents, after Germany's decision to phase-out in 2000, and in reaction to the decision to build the first EPR plant in Flamanville, in 2005. ${ }^{8}$ Looking at public opinion data and at the comparative history of anti-nuclear social movements thus reveals a gap between stable and persistent policy choices, over time, and weak and fluctuating public support for these choices. How can such a gap be explained, with respect to policy decisions of primary political, economic, social and industrial importance?

\section{A non-salient issue?}

The disconnection between the preference of the median voter and the decisions of nuclear policy in France could be rendered possible by a low salience of this issue in the public sphere. In the case of the US nuclear energy policy, Baumgartner and Jones (1993) have shown how crucial issue salience in the media is for understanding policy change. Faced with the absence of a "most important problem" barometer, we explored this possibility on the basis of a study of media coverage of nuclear energy problems, with a focus on Le Monde. 9 The high inter-media consistency observed in media studies (Eilders 2002; Vliegenthart and Walgrave 2008) justifies using this newspaper as a proxy for the French media agenda. Le Monde is generally acknowledged as the leading paper in France over the entire post-war period and its agenda-setting role has been shown to find expression in other media - the 
daily Libération, the weekly magazines Le Point and L'Express and the news in the public TV channel France 2 - taking up Le Monde's issue priorities (Blanchard 2010: 325-334). Figure 2 provides an overview of the salience of nuclear energy in Le Monde between 1977-2012, measured as the number per year of articles published on this topic.

Figure 2 about here

Our data suggests considerable variations in the visibility of the nuclear issue in the media. Attention to this issue was consistently very high by the end of the 1970s, when continuous anti-nuclear protest and the Three Mile Island accident in 1979 provided fuel for the news media. In 1977, on average, more than 2 articles per day were devoted to nuclear energy, often on the front page. This level of importance decreased and remained, during periods of routine coverage, at a non-negligible level of about 100 articles a year. Occasionally, nuclear energy gained particular prominence in the media, notably on three occasions. First, as expected, the Chernobyl accident in 1986 attracted much attention, with more than one article per day, and an intensity of coverage still above average in 1987. A new peak in attention occurred in 1996-1997, thanks to a combination of factors: the commemoration of Chernobyl in 1996, a controversy on the nuclear fuel reprocessing plant of La Hague, shaped by the publication of a scientific study in 1997, a spectacular and professional campaign carried out by Greenpeace France (Baisnée 2001), a debate opened by the Green Party and their ministers about the dismantling of the fast breeder reactor Superphénix, as well as German discussions regarding the future of nuclear energy. More recently, media attention paid to nuclear energy has risen from 2005, with a peak in 2007 in the context of the building of EPR power plants after a long pause, of the debate regarding nuclear dissemination (often related to the Iranian nuclear program), global warming and the potential role of nuclear energy in the reduction of $\mathrm{CO} 2$ emissions, energy costs and availability, the "nuclear renaissance" and the related opportunities for the French nuclear industry. Attention remained high in 2008, notably due to incidents at two French fuel cycle facilities, the uranium waste treatment plant of Tricastin and the Cerca research reactor fuel fabrication facility in Romans. The data presented in Figure 2 does not cover the most recent years, but nuclear energy certainly acquired a historic level of visibility in the months following the Fukushima accident and during the 2012 presidential campaign (Brouard et al. 2013).

Thus, attention on nuclear energy has gone 'up and down' (Downs 1972), but even in periods of routine coverage, nuclear energy is present in the media. In the period 1977-2012, at least five critical moments opened windows of opportunity to politicize the nuclear issue - all the more as several of them, in particular in the second half of the 1970s and after Chernobyl, correspond to phases of fading public support for nuclear energy. In addition, if the second half of the 1980s is not marked by any peak in media attention, there is a clear trend towards more visibility, coupled with growing distrust on part of the citizens. The hypothesis of a low salience of nuclear energy issues can thus not explain why the predominantly negative attitudes of French citizens towards nuclear energy has had virtually no impact on the course of French nuclear energy policy.

\section{4) 'Kept off” the parliamentary agenda?}

When dealing with this French exception, some scholars point to the specificity of the French scientific community, which is considered to be smaller and more homogenous than in other countries, with a quasi monopoly of the Corps des Mines graduates in key positions and a 
concentration of $\mathrm{R} \& \mathrm{D}$ resources towards research carried out within the state controlled institutions, EDF and the CEA (Baumgartner 1990; Delmas and Heinman 2001: 449; Schneider 2009). This literature has revealed strong links between nuclear research, the nuclear industry and nuclear policy. Boudia describes how policymakers, scientists and industrialists in charge of nuclear programs have responded to the growing public distrust with the creation of information and public relation devices (Boudia 2003) and how they have used scientific expertise in order to promote the social acceptability of nuclear energy and to resist social protest (Boudia 2008).

Nonetheless, since the mid-1970s, French scientists, in particular nuclear physicists have mobilized and signed public appeals against nuclear energy (Topçu 2006), so that some scientific expertise might back attempts to modify the direction of French energy policy. Famous examples are the founding mobilization of thousands of scholars, in 1975, and the establishment of the Commission for Independent Research and Information on Radioactivity (CRIIRAD in French), an organization created after Chernobyl with the objective of providing independent measures of radioactivity. More importantly, the concentration of research funding on projects related to nuclear energy, carried out at the EDF and the CEA, result from political decisions which could have been politicized, for instance by anti-nuclear MPs. The adoption of a law for environmental protection on 3 August 2009 may illustrate this argument: it was decided to rebalance research funding on energy in favor of "clean" energy sources, with the objective of spending the same amount on them as on nuclear energy by 2012. Similarly, Barthe (2006) has shown that the "irreversibility" of choices regarding nuclear waste management, commonly acknowledged until the 1990s, resulted from the way this political problem was constructed: alternative management options were left aside, thanks to political considerations, among others. Barthe shows how some actors have called this irreversibility into question since the 1990s, providing them with an opportunity to politicize nuclear waste in political arenas.

In a related vein, most authors explain that French citizens' distrust towards nuclear energy was not channeled into policymaking with respect to a decision-making process described as "restrictive", "technocratic" and "bureaucratic" (Kitschelt 1986; Jasper 1988; Rucht 1994; Delmas and Heinman 2001; Schneider 2009), which is supposed to have kept "nuclear power off the political agenda" (Baumgartner 1990). In this view, policymaking is dominated by the executive, in interaction with experts, technocrats, managers and administrators of the nuclear sector. Crucial decisions are taken behind close doors, with little room left for a democratic or political debate over energy policy choices. The institutional setting thus leaves no chance for the polarization of French public opinion finding any expression in the politicization of nuclear energy policy in either party or parliamentary debates.

The central state, the executive and the central administration indeed play a crucial role in nuclear policymaking, both as to expertise and decision-making (Lucas 1979; Rucht 1994; Delmas and Heinman 2001). The CEA and EDF developed plans that were submitted to the government's approval (often to the ministries of industry, research, defense and environment) and, in the Fifth Republic, to the President. EDF and CEA were transformed and partially privatized in the 2000s but the influence of the executive remains critical, notably through the appointment of chairmen and administrators in both institutions. The existence of a restricted, integrated and homogeneous policy network can thus not be denied.

However, asserting that nuclear energy issues are mostly or entirely kept off the political agenda and democratic arenas, such as the Parliament (Colson 1977; Hatch 1986: 150-4), or that there is no division of power in this field (Delmas and Heinman 2001) would be an 
exaggeration. Contrary to widespread beliefs, if initiatives and the elaboration of decisions emanate from the executive, their adoption is regularly submitted to a parliamentary vote, so that problems of nuclear energy have been a substantial part of the legislative agendas since the early 1950s. Even without counting the annual budget laws, which often contain dispositions regarding expenses or taxes related to nuclear facilities, over 50 laws dealing with nuclear energy have been voted and adopted in the French parliament since $1946 .{ }^{10}$

Concrete and major decisions involving the allocation of state credits have been scrutinized and voted on by French MPs, such as the five year plans for the development of atomic energy adopted in 1952 and 1957, the law on the experimentation of nuclear energy and on basic industries contributing to the general equipment of the country (1959), the electrical equipment program of 1961 and the creation of the EURODIF society, specializing in uranium enrichment and established in France. More recently, in 2005, parliament adopted a law defining the direction of energy policy, which firmly confirms the crucial place of nuclear electricity in the French energy mix.

Figure 3 about here

This is not to say that all choices in nuclear policy have been submitted to a parliamentary vote. Precise decisions regarding the timing, the geographical implantation and the conditions of the construction of nuclear plants mostly take the form of decrees, i.e. acts possibly taken by the executive only. However, the government has been entitled to make decrees on nuclear energy by law, most importantly the 1946 law on the nationalization of electricity and gas and the 1961 law against atmospheric pollution and odors (articles 2, 4 and 8), on the basis of which the 11 December 1963 decree set the conditions of authorization, creation and exploitation of nuclear facilities. ${ }^{11}$ When faced with growing popular contestation, this legislative setting could have been amended. This is, indeed, what occurred in 2006, when the law on nuclear transparency and security was adopted as the first (French) legislative frame specifically designed for nuclear activity. Since then, the Authority of nuclear safety plays an important role in the authorization of new plants and in ensuring transparency towards the public and parliament.

The adoption of the 2006 law, and the subsequent revision of the institutions ruling nuclear activities, have opened a window of opportunity for politicizing nuclear energy. In previous decades, already, such opportunities had been provided through the regular agenda setting of questions of nuclear cooperation (AIEA, EURATOM...) and of nuclear safety. Between 1965 and 2006, we were able to identify no less than 22 laws dedicated to matters of safety of nuclear power plants, treatment sites and radioactive waste disposal sites. Given this focus on risks and uncertainty, these deliberations could have given rise to a democratic debate on the direction of French energy policy and to an effective parliamentary scrutiny. The substantial place reserved for issues linked to nuclear energy may also be illustrated by the considerable attention devoted to it by the parliamentary committee specializing in technological and scientific issues - Office Parlementaire d'Evaluation des Choix Scientifiques et Techniques. Since its creation in 1983, 36 reports (out of 198) deal with the nuclear energy issue, with reflections on the consequences of Chernobyl, nuclear safety and security in France and beyond, the management of highly radioactive waste, the costs of the production of nuclear electricity, the life span of power plants, the future of the French nuclear sector, and so on.

In short, the institutional setting of French nuclear energy policy alone cannot be blamed for the absence of democratic debate. There is no institutional factor definitively preventing 
parliamentary representatives from making energy policy a salient issue, or from channeling citizens' negative feedback regarding French nuclear energy policy. Several nuclear development programs have been submitted to a parliamentary vote, as were the laws that have shaped the decision-making rules of nuclear energy policy. If the decision to construct new plants has not been put on the parliamentary agenda for decades, MPs have deliberated on reports covering all facets of nuclear energy, as well as on a series of laws on issues of nuclear research, cooperation, responsibility and safety. Yet, the related parliamentary debates never gave rise to any major cleavage before the first election of Green MPs in 1997. The successive plans of nuclear development and expansion in the 1950s, 1960 and 1970s were supported by all parliamentary parties. In debates over French energy policy, MPs seem to share common objectives that are very favorable to the nuclear sector: to secure nuclear activities, to legitimate them, to develop them and to convince European partners of their necessity. The absence of visible and influential controversy thus seems to result from nuclear energy being treated by MPs as a valence issue. In the remaining section of this article, we argue that this depoliticization cannot be understood without party politics and coalitionrelated strategies into account.

\section{5) Party politics and the misfit between opinion and policy choices}

\section{Vote-related incentives to contest nuclear energy}

A reversal in French nuclear energy policy would have required an agent implementing an anti-nuclear policy. Parties' incentives to respond to citizens' skepticism towards nuclear energy may be shaped by the preferences among their voters. Figure 4 shows that the distribution of preferences of nuclear energy differs substantially among the supporters of left and right parties. ${ }^{12}$ While the majority of the electorate of parties of the right and far-right (between 50 and 70\%) supports nuclear energy, this proportion is much smaller among Communists and Socialists (between 40 and 50\%) and especially among ecologists (20\%). The level of nuclear support among the supporters of all four traditional governing parties has been eroded since the beginning of the 1980s. For both rightist parties, the level of nuclear support decreased from three fourths in 1980 to a slight majority in 2005. After 1986, among PS sympathizers, the proportion of nuclear supporters fell and remained below $40 \%$. Voters of the Communist Party (PC), traditionally among the most pro-nuclear, are no exception to this trend. The decline of this party has been accompanied in the last 15 years by the affirmation of other far left and Trotskyist parties, whose sympathizers are as opposed to nuclear energy as the ecologist parties. In sum, the decline in support for nuclear energy affects all parties' constituencies. Coupled with mass protest against nuclear energy and the growing social, political and economic implications of this policy, this may have generated electoral incentives to advocate and promote a policy reversal, especially in the 1980s.

Figure 4 about here

The long depoliticization of nuclear energy in France: office - and policy-related incentives (1946-1989)

The growing skepticism of French voters was not followed by any realignment, as all French parties have depoliticized nuclear energy in their official positions and in their electoral campaigns. ${ }^{13}$ This depoliticization results in the low salience of matters of nuclear energy 
policy in party discourses (1) and in the broad consensus on a pro-nuclear stance, involving all parties (2). The first point may be illustrated by the marginality of nuclear energy in the electoral manifestos of the main parties between 1958 and 1988, when compared to the further relevant issues of "farmers" and "culture", as measured by the Comparative Manifesto Project (Figure 5).

Figure 5 about here

This comparison highlights the modest attention to nuclear energy within the four main parliamentary parties. Nuclear energy is mostly far less salient than other issues of similar, or even smaller, scope, be it in the manifestos of the main left parties, or in those of the Gaullist party, which is the one that historically pushed the expansion of nuclear energy. Beyond this low salience, the depoliticization of nuclear energy has also resulted, for a long time, in the convergence of the main French parties toward pro-nuclear stances. The enduring misfit between citizens' preferences on a salient issue, on the one hand, and electoral supply and policy decisions, on the other, cannot be understood without taking into account all motivations of party representatives, who are not only concerned with attracting votes, but also with policy- and office-related considerations (Müller and Strom 1999).

The interest of elected representatives in channeling the popular preference for a policy reversal varies a lot according to their party. The ideology or the political project of each party goes along with distinct policy preferences. The conservative parties anchored in the Gaullist tradition lean towards nuclear energy ${ }^{14}$, given their commitment to national independence and their proximity to representatives of the nuclear sector. On the other side of the political spectrum, the Communist Party is traditionally the most fervent advocate of nuclear energy ${ }^{15}$, which is congruent with its proximity to EDF's dominant trade union CGT, the ideological belief of the PC in the power of science and technology to transform the world, its productivist orientation and the priority set by this party on the improvement in the standard of living, job creation and preservation. The pro-nuclear stance of the PC may also be linked to the firm commitment of the USSR in massive programs of nuclear energy development, and to the high number of Communist scientists involved in French nuclear research, most notably the first director of the CEA, Frédéric Joliot-Curie. The political program of other parties, such as the Socialist Party (PS), the Centre Party (UDF) and the National Front (FN) has no such clear and straightforward implication regarding their position towards nuclear energy.

In this respect, and provided that the pro-nuclear policy was implemented by the rightist coalition involving the $\mathrm{UDF}^{16}$, a policy reversal was most likely to emanate from the PS. The only party opposed to nuclear energy was actually the small Unified Socialist Party, which partly merged with the Socialist Party in 1974. The PS is traditionally close to the only antinuclear mainstream organization, the trade union CDFT (Garraud 1979; Nelkin and Pollak 1980), and closer to anti-nuclear protest than the Communist Party, with Socialist activists heavily involved in national and local protest. However, this party did not provide the influential ally anti-nuclear movements would have needed in order to reverse the course of French nuclear energy policy. Confined in opposition for decades, the PS representatives were more concerned with accommodating the pro-nuclear stance of the main coalition partner, the PC, than with responding to anti-nuclear voters. The interplay of policy- and office-related motivations and their consequences for French nuclear policy choices is particularly striking when looking at the critical juncture of nuclear expansion and political alternation (19731985). 
The second part of the 1970s is a key moment for nuclear energy policy, with an acceleration in the rhythm of construction of new plants and a quick rise in nuclear electricity production. The development of mass anti-nuclear protest and the Three Mile Island accident could have fostered the politicization of nuclear energy in the electoral and parliamentary arenas and, at that point in time, contestation by the parliamentary opposition, or the decision to phase out, could have had huge consequences on the scope of the French nuclear program. However, parties did not respond to this challenge with a politicization of nuclear energy policy, but with a strategy of issue avoidance. This is in particular the case of the Socialist Party, faced with intense party-internal debates between pro- and anti-nuclear positions and with the necessity of accommodating the pro-nuclear Communist Party as the only possible partner for coalition building. Already at the 1973 legislative elections, the Communist and Socialist parties had defended a common manifesto that was heavily pro-nuclear, acknowledging the key role played by the CEA in the French research policy and defending state support for the development of nuclear power plants, run by a public nuclear industry. Focused on the objective of seizing power thanks to an alliance with the PC, the PS ignored the peak of antinuclear protest in France and centered its 1978 campaign on other issues. After the leftist alliance came close to winning a majority, the likely perspective of winning the 1981 presidential election made alternation and office even more the priority.

The common platform of PS and PC had to be defined on a common denominator: state intervention in the economy through nationalization and an active industrial policy provided the ground for a coalition agreement. From the point of view of each party, politicizing nuclear energy may have attracted more votes but would undoubtedly have undermined a leftwing coalition and thereby rendered impossible the 1981 alternation. This calculus sheds light on the strategy pursued by both parties. On the one hand, the Socialist Party adopted a soft stance: limiting the nuclear program to the nuclear plants already under construction, taking time for a national debate, holding a referendum on nuclear energy development, and enacting legislation guaranteeing the transparency of nuclear plant security. The socialist candidate and future President François Mitterrand also promised a moratorium on the construction of any new nuclear plant. On the other hand, the manifesto presented by the Communist Party was the first to keep silent on nuclear strategy and, since then, this party has mostly omitted the topic.

Policy-related arguments went against a phasing out of the nuclear program as well. In the 1970s, François Mitterrand had steadily emphasized the importance of remaining independent and even promoted the idea of turning back to the French graphite technology. A nuclear phasing out would have also undermined the prospects of the macro-economic policy planned by the French left. Nuclear energy was seen as an illustration of the merits of state-owned companies for building and exploiting large infrastructures, but also as a source of cheap energy for future industry development and a sector employing thousands of employees. In addition, most nuclear plants were already under construction, or nearly finished by 1981, so that a drastic phasing out would have been very costly. The most expensive part of the nuclear program had already been realized and hence would have caused considerable stranded investment, on which costs linked to the search and the funding of alternative energy supply on the market would have been added. The corresponding funding would not have been available for the nationalization policy strongly desired by the coalition of the left.

As long as the entry costs into the French political system were high enough to forbid any anti-nuclear party being pivotal, the Socialist Party had incentives to stick to nuclear energy. After the left coalition won the presidency and a legislative majority in 1981, only symbolic 
pay-offs for anti-nuclear activists were delivered, as for example the criticisms against the undemocratic nuclear policymaking implemented by the rightist government (e.g. the location of the nuclear plants) before 1981, the 6 month moratorium, and the cancellation of the Plogoff nuclear plant. These symbolic pay-offs challenged neither the principle of using nuclear energy, nor the building of new plants after 1981. Indeed, even two years after the Chernobyl accident, the Socialists presented to the 1988 national elections the most pronuclear platform ever: "Which country is the only one that succeeded in developing nuclear energy in order to overcome the scarcity of our natural resources? It is ours, because it succeeded in organizing a 20-year plan, which no private company would have been able to do". Given the skepticism, which prevails in French public opinion, this situation generates a misfit between the preferences expressed by citizens and party representatives. In 1982, the "French and Science" barometer indicates that around $70 \%$ of citizens opposed to nuclear energy sympathized with pro-nuclear parties. This figure remained high in the following decades, reaching nearly $90 \%$ in 1989 . The relevance of this explanation of the continuity of the French nuclear policy is underscored by the contrast with the patterns stemming from another critical juncture.

\section{Changing coalition-related incentives with limited policy consequences: the lack of policy opportunities (1989 - 2012).}

If the ecologist movement had run in the French national elections since the presidential contest of 1974 (gaining 1\%), it became a relevant player only from the late 1980s. This situation changed from 1989, with the Greens' breakthrough at the municipal elections in March and at the European elections in June. In 1992, for the first time, ecologists were successful in the 1992 regional elections, which allowed them to be represented in a decisionmaking institution for the first time. With $14.3 \%$ of votes, more than two hundred ecologists entered the French regional councils. The distribution of seats and political parties located the two ecologist parties as pivotal players in many regions, as they formed regional coalitions with either right or left parties, and provided external support for formal minority governments (Brouard 1999). The 1993 legislative and the 1995 presidential elections confirmed the ecologists' electoral strength. Despite the instability of their organization and of their leadership, the Green party became increasingly relevant and strategic. The rise of this party was associated to an emphasis on new issues, among which, nuclear energy was particularly important. In the 1990s, the Greens were the only party addressing the environmental issue, with concerns regarding nuclear risks and decision procedures judged "undemocratic" and too centralized. Issue avoidance and consensus regarding nuclear energy in electoral competition were suddenly broken by the emergence of the Green Party. As shown in Figure 5, the Green party devotes a higher share of its programs to nuclear energy. More importantly, the concern expressed by the Green Party regarding long-term pollution and industrial risks implies strong anti-nuclear policy preferences.

The PS and, above all, the PC simultaneously saw their electoral support shrinking and felt pressure from the Green Party electorally, given the attractiveness of the Greens in the leftist constituency; politically, with new issues entering the electoral agenda; and strategically, with the Greens becoming a pivotal player in potential left coalitions. This development changed the incentives to politicize nuclear energy. In a nutshell, the PS faced the challenge of limiting electoral losses, dealing with new issues, and remaining in the capacity of leading a left coalition, which would probably have to include the Greens. PS representatives acknowledged the necessity of signaling their willingness to form a coalition with the Green Party and their openness to their policy proposals. These considerations regarding an 
anticipated coalition with the Greens probably explain why pro-nuclear arguments vanished from the PS manifesto in 1993 and why the PS substantially revised its discourse in the 1997 legislative campaign, adopting a much more negative tone towards nuclear energy: "We will change the course of French energy policy by adopting a moratorium on the building of nuclear plants, by increasing the incentives to energy saving and to the development of alternative energy sources. We will close the fast breeder reactor Superphénix."

Nuclear policy was for the first time affected by an effective Green pressure in 1997-1998, when Greens entered the plural left coalition (1997-2002) with the PS and the PC. The government decided on the closure of the experimental plant running the fast-breeder reactor Superphénix. Yet, this reversal was mainly symbolic and did not hinder the connection of new nuclear plants to the electricity grid and a peak in nuclear electricity production. The promised moratorium on nuclear plant construction was never voted on, even if it was de facto implemented. This is not necessarily linked to Greens being in government, as the nuclear development plan was already fully realized and as no nuclear plant reached its projected end of life during this period. Nevertheless as soon as the rightwing coalition came back to power in 2002, the nuclear program was immediately re-launched with the decision to build a new plant in Flamanville, followed by a second one in 2009, planned in Penly. If the Greens did not achieve a reduction of the weight of nuclear energy, they probably precluded a further extension of the French nuclear program as long as they were in office. Given the highly constraining legacy of past policy choices, downsizing the nuclear program would have been more costly in 1997 than in 1981: the discrepancy between political time and policy time gave the Greens little opportunity to further challenge French nuclear policy.

The logic induced by the changing coalition-related incentives has persistent effects. The nuclear issue became contentious during the last two waves of presidential and parliamentary elections. In 2007, presidential candidate Ségolène Royal and the Socialist Party manifesto announced for the first time a decrease in the proportion of nuclear energy through an increase in the share of renewable energy by $20 \%$ of total energy consumption by 2020 (and $50 \%$ in a longer term). The conservative party candidate, Nicolas Sarkozy, reacted to this proposition by stressing the merits of nuclear energy in terms of $\mathrm{CO}_{2}$ emissions and comparative industrial advantage, so that this issue was hotly discussed during the TV debates involving the opposing candidates, which took place between the two rounds of the presidential election. The visibility of questions related to nuclear energy was even stronger in the run up to the 2012 national elections which took place in the aftermath of Fukushima, and in the context of the decisions of several countries to phase out the use of nuclear energy. The PS took a more critical position and promised to reduce the share of nuclear energy in electricity production by $25 \%$ before 2025 , to open a debate over energy policy, to set a moratorium on the construction of new plants until the end of this debate, to close the aging Fessenheim plant and to give up the construction of a further EPR in Penly. Public controversies resulted from the decision of the conservative party UMP and of the executive to politicize their pro-nuclear stance and to frame nuclear energy in terms of employment, purchase power and reliability. As a result, the issue seems to be absorbed by the traditional left-right cleavage, with parties on the left (except the PC) being more opposed to nuclear energy than parties on the right (Brouard et al. 2013). According to our theoretical perspective, under these political conditions, democratic responsiveness is more likely within the limits of the policy legacy. The 2012 political alternation was associated with 3 policy decisions: the oldest nuclear plant (Fessenheim) will be shut down in 2016-2017 despite the recent authorization of the extension of its life span; the nuclear plant under construction (Flamanville) will be finished and connected to the grid; the newest project 
(Penly) is canceled. Nevertheless any long term and effective policy effect remains to be observed.

\section{CONCLUSION}

This paper contributes to the study of the role of democratic responsiveness in policymaking. This theoretical perspective also allows us to cast fresh light on the determinants of French nuclear energy policy. Based on the analyses of original longitudinal data on public opinion, parliamentary activities, public policy developments and party politics over the post-1945 period, we question two current explanations for the unique stability of pro-nuclear choices in France. First, our measure of public mood toward nuclear energy shows that this stability does not reflect a pro-nuclear climate of opinion: we observe a persistent gap between French public opinion and policy choices. As we demonstrate that nuclear energy has been on the agenda for both the media and parliament for more than 50 years, this result suggests that, even regarding salient issues, dynamics of democratic responsiveness are less strong and automatic than suggested in the opinion-policy literature. Second, arguments in terms of technocracy, interest groups, path dependence and "constraints" of all kinds cannot fully account for the observed lack of democratic responsiveness. We contend that this explanation has to be complemented with respect to a neglected variable: party politics.

The continuity of French pro-nuclear policy does indeed appear to be rooted in the issueavoidance strategy of the main political parties, reinforced by the increasing inertia of past decisions on nuclear energy policy. The historical lack of strategic incentives to encourage the main parties to focus on this issue can be explained by considerations relating to policy, office and vote. On the one hand, parties on the right of the political spectrum were policy-oriented in their pro-nuclear stances, as was the PC. These pro-nuclear formations had no interest in politicizing an issue over which they were not in tune with the majority of French voters. On the other hand, the Socialist Party had to accommodate its communist coalition partner and sought to focus on issues that were not contentious within the PC. These constraints at the party level have become combined with the imperative for individual legislators to be renominated by their party for the next election, which created incentives to avoid questions of nuclear energy policy in the parliamentary arena and to observe party discipline when voting over nuclear energy. The comparative analysis of two critical junctures of French nuclear history underlines the relevance of our explanation. As long as the Greens remained a marginal party, the Three Mile Island and the Chernobyl accidents did not shape party discourses of nuclear energy: for a long time, neither major shocks, nor the resulting social mobilization, and shifts in public opinion, affected French nuclear policy. The pro-nuclear consensus was broken only after the Green Party became a potential coalition partner for the Socialist party: the PS manifesto has become less and less pro-nuclear since then, in order to preserve the pre-electoral coalition with the Greens.

Beyond the case of nuclear energy, we hope that this article is convincing about the potential of studying politics and policies together, even in the case of a policy field marked by a high degree of technical content, heavy path dependence, powerful interest groups, and considerable economic and natural constraints. The influence of public opinion and mass protest is neither a priori negligible, nor automatic and autonomous, but relies on further mediating variables. Our results confirm observations made by other scholars of the importance of issue salience to understand precisely when public opinion is translated into public policy (Monroe 1998; Gilbert and Henry 2009; Culpepper 2011) and suggest that salience is not a sufficient condition. A further, crucial variable should be considered in models of responsiveness: the inter-party dynamics of contention across issues. Strategic 
incentives to politicize nuclear energy appear to be a necessary condition for responsiveness to occur in France. Nevertheless, more comparative work is required across policies and polities in order to understand the interplay between salience, institutions and party politics in the responsiveness process. For example, how the institutional setting might mitigate the effect of party politics is a promising area. A systematic assessment of the conditions under which public opinion may shape policies is currently one of the most challenging research agendas in public policy analysis.

\section{References}

Arnold C. and Franklin M.N. (2012) Introduction: Issue Congruence and Political Responsiveness, West European Politics, 35 (6), 1217-1225.

Baisnée O. (2001) Publiciser le risque nucléaire. La polémique autour de la conduite de rejets en mer de l'usine de la Hague, Politix, 14 (54), 157-181.

Bale T. (ed.) (2008) Immigration and integration policy in Europe, Abingdon: Routledge.

Barthe Y. (2006) Le pouvoir d'indécision. La mise en politique des déchets nucléaires, Paris: Economica.

Bataille C. and Galley R. (1999) Rapport sur l'aval du cycle nucléaire: Tome II, les coûts de production de l'électricité. Rapport de l'Office parlementaire d'évaluation des choix scientifiques et technologiques 1359, available online: http://www.assembleenationale.fr/11/rap-off/r1359-02.asp\#P23 776.

Baumgartner F.R. (1990) Keeping Nuclear Power Off The Political Agenda, Paper presented at the Workshop on the Comparative Political Economy of Science: Scientists and the State, Los Angeles, CA, January 12-14.

Baumgartner F.R. and Jones B.D. (1993) Agendas and Instability in American Politics, Chicago and London: University of Chicago Press.

Baumgartner F.R., De Boef S. L. and Boydstun A. E. (2008) The Decline of the Death Penalty and the Discovery of Innocence, Cambridge: Cambridge University Press.

Blais A., Blake D. and Dion S. (1993) Do Parties Make a Difference? Parties and the Size of Government in Liberal Democracies, American Journal of Political Science 37 (1), 40-62.

Blais, A., Blake, D. and Dion S. (1996) Do Parties Make a Difference? A Reappraisal, American Journal of Political Science, 40(2), 514-520.

Blanchard P. (2010) Les médias et l'agenda de l'électronucléaire en France. 1970-2000, PhD Thesis. Paris Dauphine University.

Bonneval L. and Lacroix-Lasnoë C. (2011) L'opinion publique et européenne et le nucléaire après Fukushima, Paris: Fondation Jean Jaurès.

Boudia S. (2003) Exposition, institution scientifique et médiatisation des controverses technoscientifiques: le cas du nucléaire (1945-2000), Mediamorphoses, 9, 47-52.

Boudia S. (2008) Sur les dynamiques de constitution des systèmes d'expertise scientifique: le cas des rayonnements ionisants, Genèses, 70, 26-44.

Brouard S. (1999) Partis politiques et politiques publiques dans les gouvernements locaux: l'exemple des groupes et élus écologistes dans les régions métropolitaines, $\mathrm{PhD}$ thesis, Institute of political science of Bordeaux.

Brouard S., Gougou F., Guinaudeau I. and Persico S. (2013) Un effet de campagne: le déclin des Français au nucléaire en 2011-2012, Revue française de science politique, forthcoming.

Burstein P. (1998) Bringing the public back in: should sociologists consider the impact of public opinion on public policy, Social forces, 77 (1), 27-62.

Chick M. (2007) Electricity and Energy Policy in Britain, France and in the United States since 1945, Cheltenham: Edward Elgar.

Colson J.-P. (1977) Le nucléaire sans les Français, Paris: Maspero.

Culpepper P. (2011) Quiet Politics and Business Power. Coroporate Control in Europe and Japan, Cambridge: Cambridge University Press.

Dahl R. (1971) Polyarchy. Participation and Opposition, New Haven: Yale University Press. 
Delion A. G. and Durupty M. (2010) Chronique du secteur public économique, Revue française d'administration publique, 133, 169-177.

Delmas M. and Heinman B. (2001) Government credible commitment to the French and American Nuclear Power Industries, Journal of Policy Analysis and Management, 20 (3), 433-456.

Downs A. (1972) Up and Down with Ecology: The Issue Attention Cycle, Public Interest, 28, 38-50.

Downs A. (1957) An Economic Theory of Democracy, New York: Harper.

Eilders C. (2002) Conflict and Consonance in Media Opinion, European Journal of Communication, 17 (1), 25-63.

Erikson R.S., MacKuen M.B. and Stimson J.A. (2002) The Macro Polity, New York: Cambridge University Press.

Findlay T. (2011) Nuclear Energy and Global Governance. Ensuring Safety, Security and NonProliferation, London and New York: Routledge.

Garraud P. (1979) Politique électro-nucléaire et mobilisation: la tentative de constitution d'un enjeu, Revue française de science politique, 29, 448-474.

Gilbert C. and Henry E. (2009) Comment se construisent les problèmes de santé publique, Paris: La Découverte.

Gilens M. (2005) Inequality and Democratic Responsiveness, Public Opinion Quartely, 69 (5), 778796.

Guillaumat-Taillet F. (1987) La France et l'énergie nucléaire: réflexions sur des choix, Revue de l'OFCE, 19 (1), 189-227.

Hadjilambrinos C. (2000) Understanding technology choice in electricity industries: a comparative study of France and Denmark, Energy Policy, 2, 1111-1126.

Hakhverdian A. (2010) Political Representation and its Mechanisms: A Dynamic Left-Right Approach for the United Kingdom, 1976-2006, British Journal of Political Science, 40, 835-856.

Hakhverdian A. (2012) The Causal Flow between Public Opinion and Policy: Government Responsiveness, Leadership, or Counter Movement? Evidence from the United Kingdom, West European Politics, 35 (6), 1386-1406.

Hatch M. T. (1986) Politics and nuclear power. Energy policy in Western Europe. Lexington, KY: University Press of Kentucky.

Hartley T., Russsett B. (1992) Public opinion and the common defense: who governs military spending in the United States? American political science review, 86 (4), 905-915.

Hecht G. (1998) The Radiance of France: Nuclear Power and National Identity After World War II, Cambridge: MIT Press.

Hill K. Q. and Hinton Andersson A. (1995) Pathways of representation: a causal analysis of public opinion-policy linkages, American journal of political science, 39 (4), 924-935.

Hobolt S. and Klemmensen R. (2008) Government Responsiveness and Political Competition in Comparative Perspective, Comparative Political Studies, 41 (3), 309-337.

Hutter S. (forthcoming) Protesting Culture and Economics in Western Europe: New Cleavages in Left and Right Politics, Minneapolis: University of Minnesota Press.

Jacobs L. and Shapiro R.Y. (1994) Studying Substantive Democracy, PS: Political Science and Politics, 27, 9-17.

Jacobs L. and Shapiro R. Y. (2000) Politicians Don't Pander. Political Manipulation and the Loss of Democratic Responsiveness, Chicago: University of Chicago Press.

Jasper J.M. (1988) The Political Life Cycle of Technological Controversies, Social Forces, 67 (2), 357-377.

Jasper J.M. (1990) Nuclear Politics: Energy and the State in the United States, Sweden, and France, Princeton, NJ: Princeton University Press.

Jopke C. (1993) Mobilizing Against Nuclear Energy: A Comparison of Germany and the United States, Berkeley: University of California Press.

Kiersch G. and von Oppeln S. (1983), Kernenergiekonflikt in Frankreich und Deutschland, Berlin: Wissenschaftlicher Autoren-Verlag.

Kitschelt H.B. (1986) Political Opportunity Structures and Political Protest: Anti-Nuclear Movements in Four Democracies, British Journal of Political Science, 16, 57-85.

Kriesi H. et al. (1995) New Social Movements in Western Europe, Minneapolis: University of Minnesota Press. 
Lucas N. D. (1979) Energy in France: Planning, Politics and Policy, London: Europa Publications.

Mair P. (2006) Ruling the Void: The Hollowing Out of Western Democracy, New Left Review, 42, 2551.

Manza J. and Cook F. L. (2002) Policy Responsiveness to Public Opinion: The State of the Debate. In J. Manza, F.L. Cook and B.I. Page (eds.), Navigating Public Opinion: Polls, Policy and the Future of American Democracy, New York: New York University Press, 17-32.

Monroe A.D. (1998) American Public Opinion and Public Policy, 1980-1993, Public Opinion Quartely, 62, 6-28.

Mortensen P.B., Green-Pedersen C., Breeman G., Chaqués-Bonafont L., Jennings W., John P., Palau A.M. and Timmermans A. (2011) Comparing Government Agendas: Executive Speeches in the Netherlands, United Kingdom, and Denmark, Comparative Political Studies, 44 (8), 973 1000 .

Müller W.C. and Strom K (1999) Policy, office, or votes? How political parties in Western Europe make hard decisions, Cambridge; New York: Cambridge University Press.

Nelkin D. and Pollak M. (1980) The Political Parties and the Nuclear Energy Debate in France and Germany, Comparative Politics, 12, 127-141.

Nelkin D. and Pollak M. (1981) The Atom Besieged: Extraparliamentary Dissent in France and Germany, Cambridge: MIT Press.

Page B.I., Shapiro R.Y. (1983) Effects of Public Opinion on Policy, The American Political Science Review, 77, 175-190.

Persico S., Froio C. and Guinaudeau I. (2012) Action publique et partis politiques: l'analyse de l'agenda législatif français entre 1981 et 2009, Gouvernement et action publique, 1, 11-30.

Pierson P. (2000) Increasing Returns, Path Dependence, and the Study of Politics, American Political Science Review, 94 (2), 251-67.

Pitkin H. (1967) The Concept of Representation, Berkeley: University of California Press.

Ramana M.V. (2011) Nuclear Power and the Public, Bulletin of the Atomic Scientists, 67 (4), 43-61.

Rose R. (1984) Do Parties Make a Difference? Basingstoke: Macmillan.

Rucht D. (1994) The Anti-nuclear Power Movement and the State in France, in H. Flam (ed.), States and Anti-Nuclear Movements. Edinburgh: Edinburgh University Press, 129-162.

Schneider M. (2009) Nuclear Power in France - Trouble Lurking Behind the Glitter. In L. Mez, M. Schneider and S. Thomas (eds.), International Perspectives on Energy Policy and the Role of Nuclear Power. Brentwood, UK: Multi-Science Publishing.

Schumpeter J. A. (1942) Capitalism, Socialism and Democracy, New York: Harper \& Row.

Soroka S.N., Wlezien C. (2010) Degrees of Democracy. Politics, Public Opinion, and Policy, Cambridge: Cambridge University Press.

Soroka S.N. (2002) Agenda-Setting Dynamics in Canada, Vancouver: UBC Press.

Stimson J.A., Tiberj V., Thiébaut C. (2010) Le mood, un nouvel instrument au service de l'analyse dynamique des opinions, Revue française de science politique, 60 (5), 901-926.

Stimson J.A. (1999) Public Opinion in America. Moods, Cycles, and Swings, Boulder: Westview Press, $2^{\text {nd }}$ edition.

Stimson J.A., et al. (1995) Dynamic Representation, American Political Science Review, 89, 543-565.

Topçu S. (2006), Nucléaire: de l'engagement «savant » aux contre-expertises associatives, Natures, Sciences, Sociétés, 14, 249-266.

Vliegenthart R. and Wlagrave S. (2008) The contingency of intermedia agenda-setting: a longitudinal study in Belgium, Journalism and mass communication quarterly, 85 (4), 860-77.

Wlezien C. (1995) The Public as Thermostat: Dynamic Preferences for Spending, American Journal of Political Science, 39 (4), 981-1000.

Wlezien C. (2004) Patterns of Representation: Dynamics of Public Preferences and Policy, The Journal of Politics, 66 (1), 1-24.

Wlezien C., Soroka S.N. (2012) Political Institutions and the Opinion-Policy Link, West European Politics, 35 (6), 1407-1432.

Zohinhöfer R. (2009) How Politics Matter When Policies Change: Understanding Policy Change as a Political Problem, Journal of Comparative Policy Analysis: Research and Practice, 11 (1), 97-115. 
Figure 1 Level of support to nuclear energy in France 1975-2012 (French "mood", with confidence

interval)

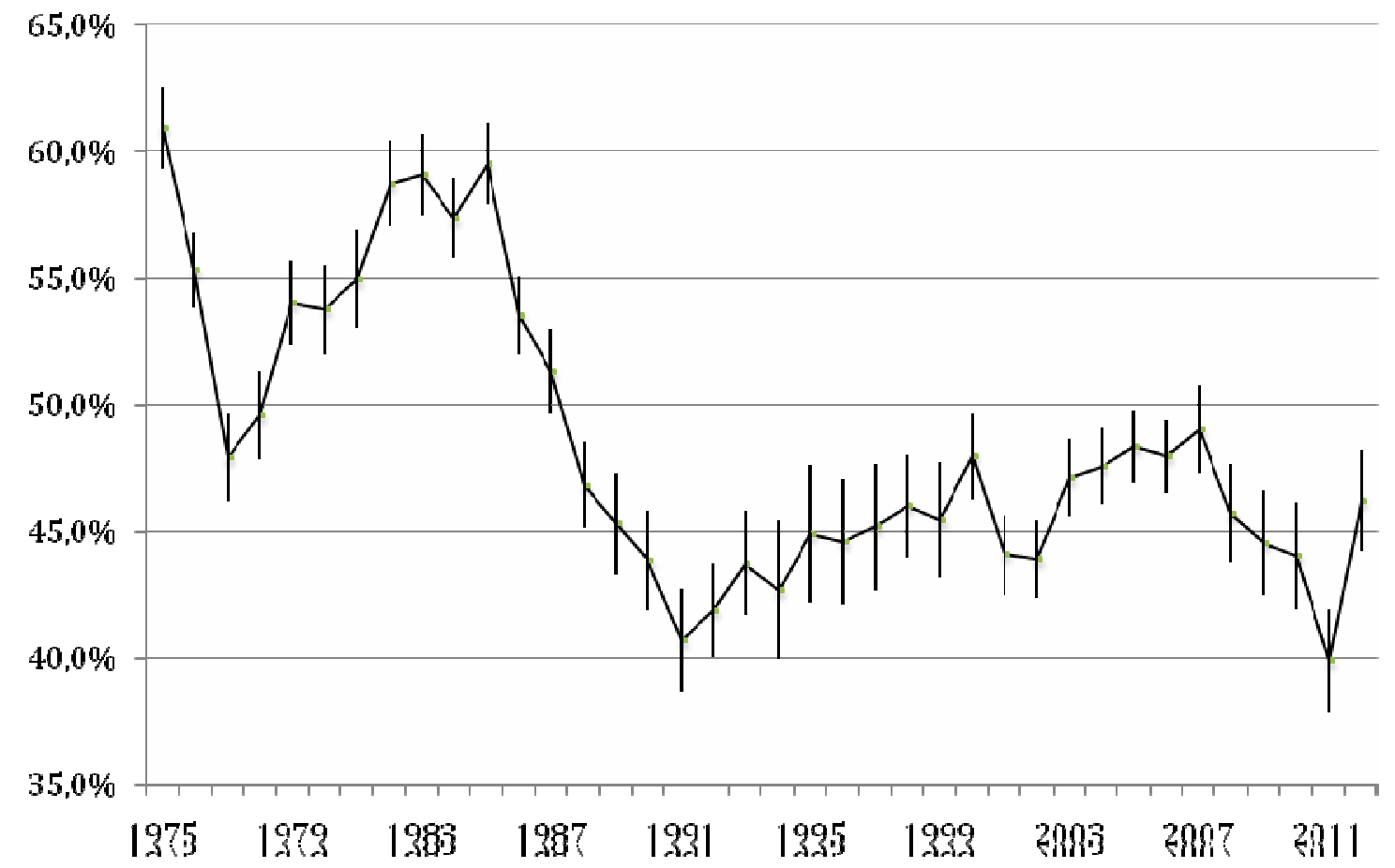

Source: Eurobarometer surveys; EDF nuclear barometer; CREDOC barometers; IRSN barometers; "The French and Science" barometer; French elections surveys (Panel electoral français; Trielec); IFOP, IPSOS and Sofres surveys (own analyses).

Figure 2 Attention to nuclear energy in Le Monde 1977-2008 (number of articles per year)

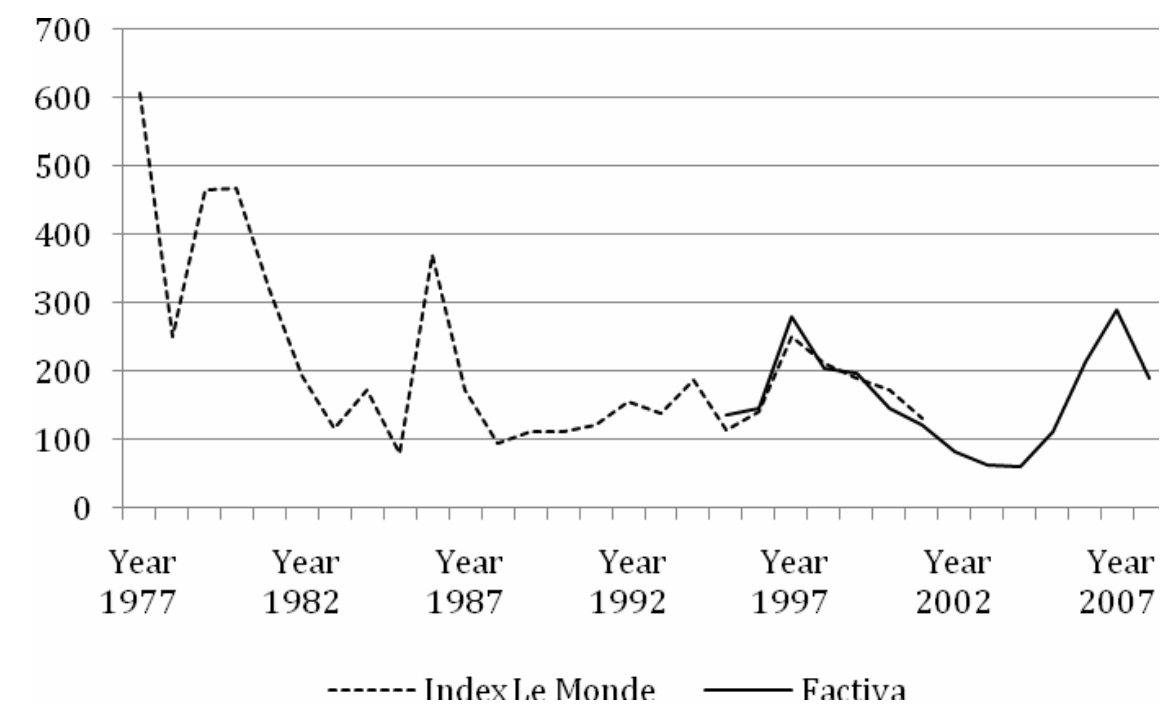

Sources: Index Le Monde; Factiva search engine. 
Figure 3 Number of laws on nuclear energy related issues (1946-2012)

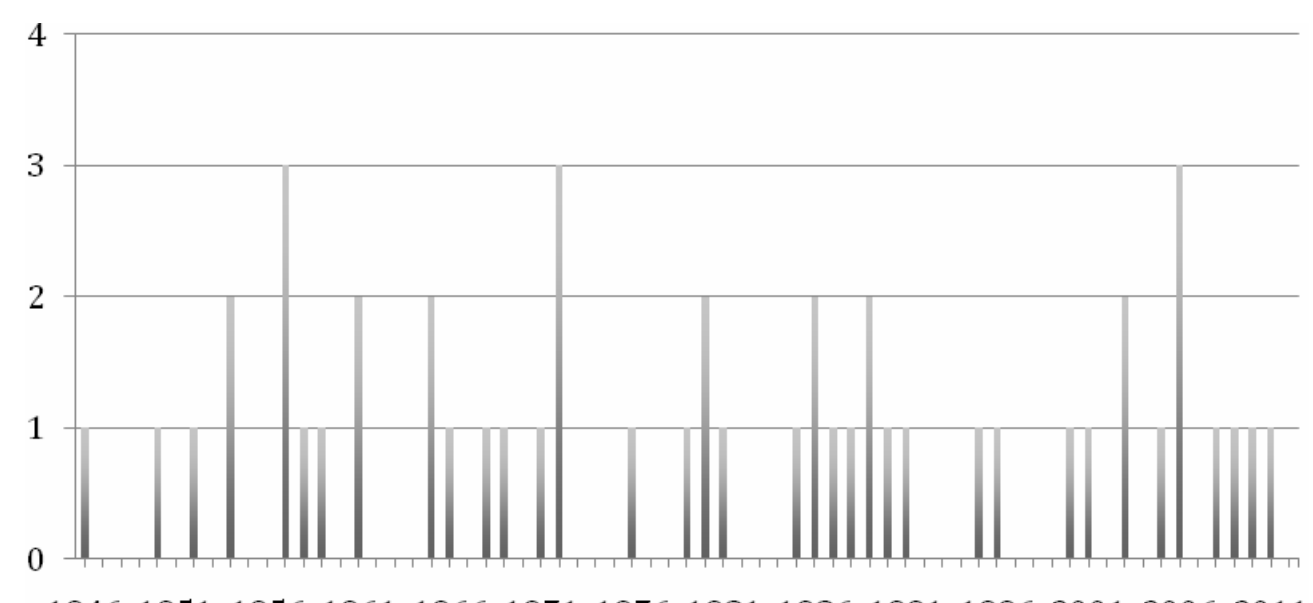

19461951195619611966197119761981198619911996200120062011

Source: Legifrance (www.legifrance.gouv.fr) 
Figure 4 Level of nuclear support among party-leaners in France, 1980-2005

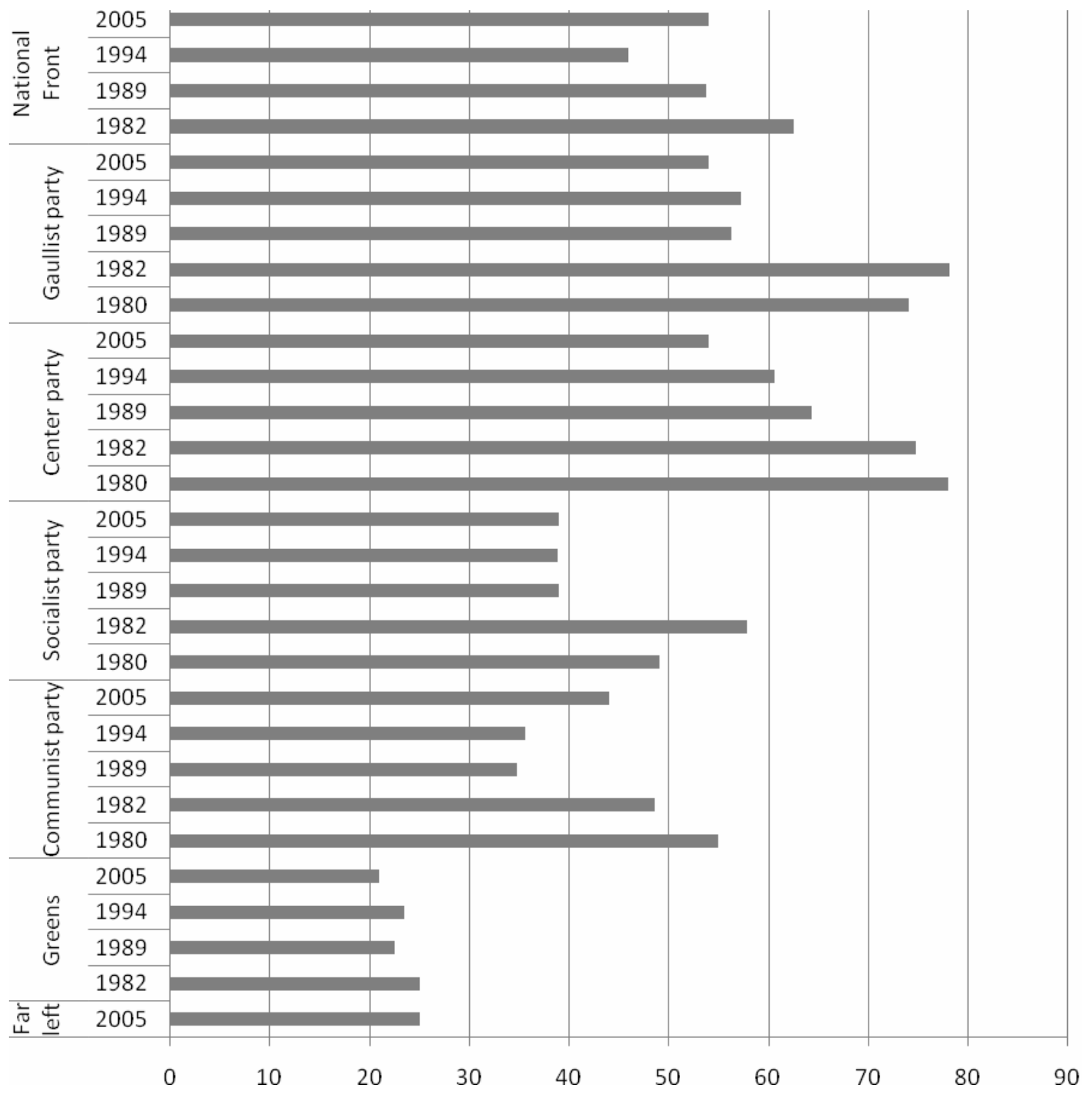

Sources: Sofres; "The French and Science"; IFOP. 
Figure 5 Attention to nuclear energy, farmers and culture in French party manifestos

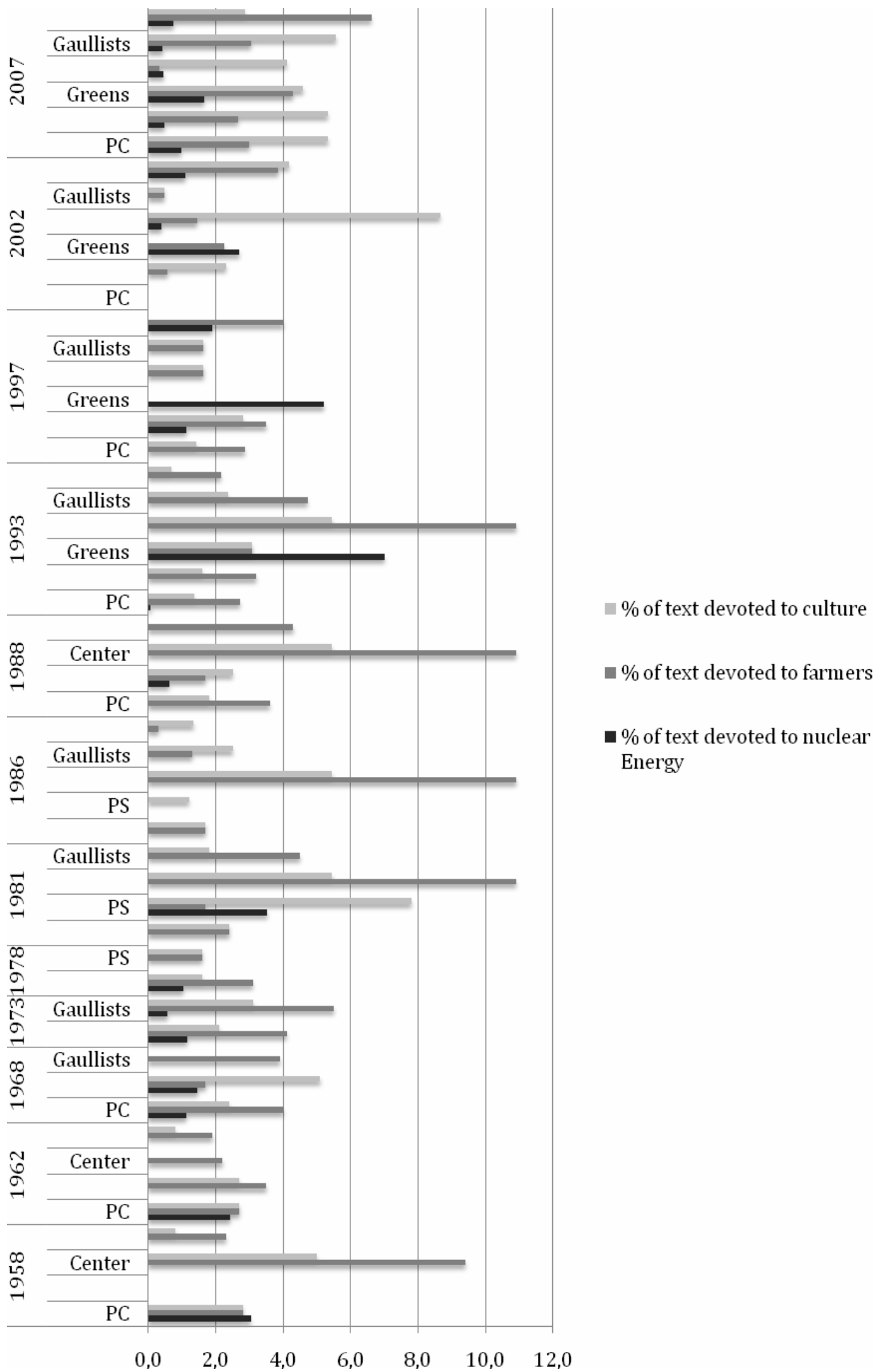

Sources: Comparative Manifestos Project; French electoral manifestos. 


\section{Appendix: List of survey questions used to compute the public mood towards nuclear energy.}

\begin{tabular}{|c|c|c|}
\hline Source & Question wording (English translation) & $\begin{array}{l}\text { Nb. of } \\
\text { data } \\
\text { points }\end{array}$ \\
\hline IRSN & $\begin{array}{l}\text { Radioactivity of nuclear plants will cause cancers. } * \text { Disagree strongly } * \text { Tend to } \\
\text { disagree } * \text { Tend to agree * Agree strongly }\end{array}$ & 15 \\
\hline IRSN & $\begin{array}{l}\text { Further nuclear power plants should be constructed. } * \text { Disagree strongly } * \text { Tend to } \\
\text { disagree } * \text { Tend to agree } * \text { Agree strongly }\end{array}$ & 3 \\
\hline EB & $\begin{array}{l}\text { All new development in the industrial field implies effort, time and money, it may also } \\
\text { involve risk. Here are } 3 \text { opinions about the development of nuclear power stations, } \\
\text { which use atomic energy for the production of electricity. Which of these } 3 \text { statements } \\
\text { comes closest to your own opinion on the development of nuclear power? } * \text { DK * } \\
\text { Worthwhile * No particular interest * Unacceptable risks }\end{array}$ & 6 \\
\hline EB & $\begin{array}{l}\text { I am going to read out to you some opinions about nuclear energy and radioactivity. } \\
\text { For each one of these, answer whether you agree completely, agree to some extent, } \\
\text { disagree to some extent, disagree completely? => Living near a nuclear power station } \\
\text { increases the risks of cancer or abnormalities in children. * DK * Agree to some extent } \\
* \text { Disagree to some extent }\end{array}$ & 6 \\
\hline EB & $\begin{array}{l}\text { I am going to read out to you some opinions about nuclear energy and radioactivity. } \\
\text { For each one of these, answer whether you agree completely, agree to some extent, } \\
\text { disagree to some extent, disagree comple+A54tely? => An accident like what } \\
\text { happened at Chernobyl could not happen in a nuclear power station in this country. * } \\
\text { DK * Agree to some extent * Disagree to some extent }\end{array}$ & 6 \\
\hline EB & $\begin{array}{l}\text { We'd like to hear your views on some important political issues. Do you agree or } \\
\text { disagree with each of the following proposals? How strongly do you feel? (Q.159B): } \\
\text { Nuclear energy should be developed to meet future energy needs. * DK * Agree } \\
\text { strongly * Agree * Disagree * Disagree strongly }\end{array}$ & 3 \\
\hline EB/Trielec & $\begin{array}{l}\text { Are you fully favourable, rather favourable, rather opposed or fully opposed to the } \\
\text { production of energy by nuclear power plants? }\end{array}$ & 8 \\
\hline EB & $\begin{array}{l}\text { To what extent would you say that producing electricity from nuclear power ... is } \\
\text { worth it from the point of view of cost? (1991: is attractive from the point of view of } \\
\text { cost?) } * \text { DK * Agree completely * Agree to some extent } * \text { Disagree to some extent } * \\
\text { Disagree completely }\end{array}$ & 3 \\
\hline CREDOC & $\begin{array}{l}\text { Are you very worried, somewhat worried, not very worried or not at all worried about } \\
\text { an accident in a nuclear power plant? } * \text { DK } * \text { Very worried } * \text { Somewhat worried } * \text { Not } \\
\text { very worried } * \text { Not at all worried }\end{array}$ & 15 \\
\hline IFOP & $\begin{array}{l}\text { Are you very worried, somewhat worried, not very worried or not at all worried about } \\
\text { nuclear power plants? }\end{array}$ & 5 \\
\hline CREDOC & Do you agree with the French nuclear energy policy? $*$ Agree $*$ Disagree $*$ DK & 8 \\
\hline IFOP & $\begin{array}{l}\text { In France, } 75 \% \text { of energy production stems from nuclear plants. In this respect, which } \\
\text { of the following opinions comes closest to yours? } * \text { At the risk of paying energy at a } \\
\text { higher price, the balance of French electricity production using nuclear plants and } \\
\text { using other sources needs to be readjusted. * The share of nuclear energy should be } \\
\text { maintained in order to get electricity at the best possible price in France, even if this } \\
\text { can imply other drawbacks. }\end{array}$ & 5 \\
\hline IRSN & $\begin{array}{l}\text { In each of the following fields, do you consider the general level of risk for the French } \\
\text { to be } * \text { high } * \text { moderate } * \text { weak? Radioactive fallout of the Chernobyl accident. }\end{array}$ & 10 \\
\hline BVA-Ifop & Would you be in favour or against the construction of new nuclear plants in France? & 2 \\
\hline CREDOC & $\begin{array}{l}\text { According to you, does the choice of nuclear energy in order to produce } 3 / 4 \text { of French } \\
\text { electricity present more advantages or drawbacks? }\end{array}$ & 28 \\
\hline
\end{tabular}




\begin{tabular}{|l|l|l|}
\hline $\begin{array}{l}\text { "Les } \\
\text { Français et } \\
\text { la science" } \\
\text { survey; } \\
\text { Sofres; } \\
\text { EDF }\end{array}$ & $\begin{array}{l}\text { Following their opinion on the development of nuclear plants, French people can be } \\
\text { classified using this type of scale. As you see, there are two big groups: those who are } \\
\text { against and those who are in favour: people can be more or less against or more or less } \\
\text { in favour. Where would you place yourself on this scale? * Does not place him or } \\
\text { herself * Scale from 1 (strongly against) to 6 (strongly in favour) }\end{array}$ & 45 \\
\hline $\begin{array}{l}\text { Sofres, } \\
\text { Trielec }\end{array}$ & $\begin{array}{l}\text { Regarding energy, two solutions are considered today: which one would you prefer? * } \\
\text { Progressively replace old nuclear plants by new ones in the same locations * Not } \\
\text { replace old plants and progressively phase out this type of energy production. }\end{array}$ & 5 \\
\hline CREDOC & $\begin{array}{l}\text { In a French nuclear plant, do you think that the risk of a dramatic accident is * high * } \\
\text { low. }\end{array}$ & 19 \\
\hline IRSN & $\begin{array}{l}\text { In each of the following fields, do you consider the general level of risks for the French } \\
\text { to be * high * moderate * weak: nuclear plants. }\end{array}$ & 15 \\
\hline IRSN & $\begin{array}{l}\text { In each of the following fields, do you consider the general level of risk for the French } \\
\text { to be* high * moderate * weak: radioative waste. }\end{array}$ & 15 \\
\hline CREDOC & Is radioactive waste properly stored in France? * No opinion * Yes * No & 19 \\
\hline CSA & Would you yourself accept living next to a nuclear plant? * No opinion * Yes *No & 2 \\
\hline IRSN & Would you accept living next to a nuclear plant? * yes * No & 23 \\
\hline Sofres & If a nuclear power plant should be settled in your region, would you oppose it? & 3 \\
\hline $\begin{array}{l}\text { EDF } \\
\text { nuclear } \\
\text { barometer; } \\
\text { IFOP }\end{array}$ & $\begin{array}{l}\text { What is your personal opinion on the use of nuclear energy in France? * Hesitating * In } \\
\text { favour * Opposed * DK }\end{array}$ & 21 \\
\hline $\begin{array}{l}\text { BVA for } \\
\text { EDF }\end{array}$ & What is your position regarding nuclear power plants? & 22 \\
\hline
\end{tabular}

${ }^{1}$ Of course, we acknowledge the stimulating debate on whether political parties matter to the policymaking (e.g. Blais et al. 1993, 1996 ; see Imbeau et al. 2001 for an overview). Our argument is that the literature tends to neglect the mediating role that political parties may play between public opinion and public policy.

${ }^{2}$ According to government statistics (http://www.statistiques.developpementdurable.gouv.fr/rubrique.php3?id rubrique $=550$ ), electricity exports were superior to imports by $70 \mathrm{TWh}$ in 1995. This trade surplus tended to diminish in the 2000s - it fell to 60 TWh in 2005 and to 26 TWh in 2009 - but remained positive.

${ }^{3}$ See the report published in 2012 by the national audit office, available online: www.ccomptes.fr/Publications/Publications/Les-couts-de-la-filiere-electro-nucleaire.

${ }^{4}$ Four huge groups had dominated the sector for a long period of time: Cogema (a CEA department dealing with $\mathrm{R} \& D$ and nuclear safety), EDF (the sole company engineering nuclear plants), the Empain-Schneider group (building the main components of the plants through its subsidiaries Framatome and Creusot-Loire), and the Alsthom-Atlantique branch of the CGE group. Since 2001, the main group has been AREVA (which was a fusion of the CEA Industry department with Framatome and Cogema).

${ }^{5}$ The level of support varies considerably if respondents are asked about their general position, on the phasingout option or on the non-replacement of aging power plants. This type of framing effect explains that two polls realized in the aftermath of the Fukushima accident generated diametrically opposite conclusions. While the Sofres poll ordered by EDF, realized on March 15th and 16th, concluded that $42 \%$ of the sample were in favor of a phasing-out, another poll performed by IFOP for the Green party estimated this share by $70 \%$.

${ }^{6}$ The data stems from regular barometers (Eurobarometer; IRSN; CREDOC; EDF), French election surveys (panel electoral français; Trielec), as well as from surveys implemented by the institutes IFOP, IPSOS, Sofres and BVA. All these surveys are based either on random or quota samples and were implemented in face-to-face or telephone interviews. The $\mathrm{N}$ is in almost all cases superior to 1000 - except, due to missing cases, in some Eurobarometer items, where the $\mathrm{N}$ still systematically remains above 900.

${ }^{7}$ People refusing to position themselves, i.e. non-respondents and respondents adopting a "neutral" position, were not included in the calculus of the ratio. By construction, the nuclear index is sensitive to the change in mind from positive to negative feelings or vice-versa, but also from indifferent and ambivalent feelings to positive and negative feelings.

${ }^{8}$ On the basis of a protest event analysis using media and other sources, Swen Hutter has recently produced an indicator of the anti-nuclear protest mobilization in eleven countries (Hutter, forthcoming). Over the 1975 to 2011 period, France (along with the Netherlands) features an intermediate level of mobilization, with fewer 
participants than Germany, Austria and Switzerland but significantly more than countries such as Britain, Italy, Spain, the US, Belgium and Sweden. However, in the second half of the 1970s, the French and the Swiss movements appear to be the strongest.

${ }^{9}$ Between 1977 and 2001, we relied on the annual Index Le Monde to study the nuclear issue coverage in Le Monde. This tool lists all articles published by the newspaper by topic and includes several categories linked to nuclear energy ("nuclear energy", "nuclear accident", "nuclear security"), allowing to count how many articles were devoted, each month, to this issue. As the annual Index Le Monde was published only until 2001, we used the thematic index of the online database Factiva to complete our time series, by counting all articles indexed as covering the topic of "nuclear energy". In order to control for possible differences between the electronic and indexed content of Le Monde, we used all the available years on Factiva (1995-2008). The analysis of the seven common years proved that a source effect exists, but that this effect is weak and both sources are highly correlated.

${ }^{10}$ A list of these laws is available upon request to the authors.

${ }^{11}$ The 1972 law authorizing the creation of enterprises exerting, on French soil, electrical activity of European interest, and the 1976 law on installations classified for environmental protection, are also quoted as a reference in many nuclear energy decrees.

${ }^{12}$ We used the same question asked in three waves of the survey 'The French and Science' fielded in 1982, 1989 and 1994. We also used two complementary surveys: a 1980 SOFRES poll using the same question wording and a 2005 IFOP survey. The level of nuclear support represents the percentage of respondents taking position in favor of nuclear energy, i.e. positioning themselves between 4 and 6 on a six-point scale going from 'strongly against nuclear plants' to 'strongly in favor of nuclear plants'.

${ }^{13}$ The following description of campaign discourses on nuclear energy has been established on the basis of the press coverage of campaigns, as well as on the party programs, as collected by the Comparative Manifesto Project, which were kindly provided by the CMP archive, located at the GESIS (Cologne). Where possible, these manifestos were completed with previously missing ones, for instance several UDF and FN programs. A list of these documents is available upon request.

${ }^{14}$ For example, as early as 1958 the Gaullist Party platform focused on the energy sector as a priority: the need to go from research about 'the resources of the atom' to industrial application was emphasized.

${ }^{15}$ From 1958 to 1978, the Communist Party had explicitly repeated the need for 'the development of a powerful and peaceful nuclear industry'.

${ }^{16}$ In 1978, the UDF party manifesto was in favor of 'the increase of our own energy resources, particularly the nuclear ones (...)' and 'the implementation of the nuclear program during the next 5 years'.

Authors:

Sylvain Brouard (s.brouard@sciencespobordeaux.fr)

Centre Émile Durkheim / Sciences Po Bordeaux

11, Allée Ausone

Domaine Universitaire

F-33607 Pessac Cedex (France)

(corresponding author) Isabelle Guinaudeau (isabelle.guinaudeau@ sciencespo-grenoble.fr)

Pacte / Sciences Po Grenoble

BP48

F-38040 Grenoble Cedex 9 (France) 